\title{
Marketing activities of vape shops across racial/ethnic communities
}

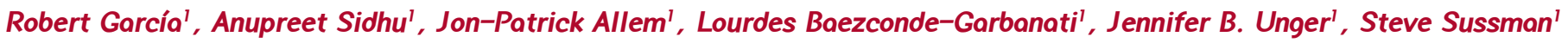

\begin{abstract}
INTRODUCTION There has been a surge in the number of vape shops in the USA. Research on the marketing practices of e-cigarette manufacturers is scarce and even less known are the practices of vape shop retailers. Past research on tobacco marketing has shown differences in the amount and content of marketing material, based on a community's demographic profile. This study examined marketing strategies in vape shops and explored differences among vape shops located in communities that differ by ethnic composition.

METHODS Data was gathered in 2014 from a pilot-study on vape shops $(n=77)$ in Los Angeles, which documented the characteristics of shops through employee interviews and in-store observations. Data were collected from shops located in communities that were predominantly, African-American $(n=20)$, Hispanic $(n=17)$, Korean $(n=18)$, or non-Hispanic White $(n=22)$. RESULTS Sixty-one percent of vape shops had advertisements (print ads and posters) for e-cigarettes and 84\% offered discounts. Vape shops in Hispanic communities were more likely to have ethnic specific marketing material compared to shops in other communities. All the shops provided customers with free samples, however those in Korean and non-Hispanic White communities had a significantly higher prevalence of customer accessible free samples.

concLusions Vape shop marketing practices differed by ethnic community. A large majority of shops provided free samples to their customers, a practice which is now banned by the FDA. It will be important to monitor how vape shops will adjust their marketing strategy because of this ban. Future research should expand on the findings presented here to provide regulators with further crucial information.
\end{abstract}

\section{AFFILIATION}

Department of Preventive

Medicine, Keck School of Medicine of USC, University of Southern California, Los Angeles, USA

\section{CORRESPONDENCE TO}

Robert García. Department of Preventive Medicine, Keck School of Medicine of USC, University of Southern California, $2001 \mathrm{~N}$ Soto St, 312-17, Los Angeles, CA 90032, USA

Email: garc617@usc.edu

\section{KEYWORDS}

vape shop, tobacco marketing, electronic-cigarettes, tobacco control policy

Received: 11 May 2017

Revised: 8 June 2017

Accepted: 15 August 2017

\section{INTRODUCTION}

The popularity of electronic cigarettes (e-cigarettes) has led to the rapid creation of a new retail environment, vape shops ${ }^{1-5}$. Vape shops specialize in selling rechargeable e-cigarettes and related accessories, including electronic liquids (e-liquids) ${ }^{1-3,5,6}$. Marketing expenditures for e-cigarettes have more than doubled between 2011 and 2012, from $\$ 6.4$ million to $\$ 18.3$ million ${ }^{7}$. However, estimates of marketing expenditures are likely to be conservative as data are derived from national retailers excluding independently owned vape shops ${ }^{7}$. Research on the marketing practices of e-cigarette manufactures is scarce $^{8}$ and even less known are the practices of vape shop retailers.

Vape shops provide an environment that facilitates interaction between employees and customers, where products and services are discussed as well as smoking cessation ${ }^{9,10}$. Research has demonstrated that vape shop owners/retailers discuss the safety of the ingredients used in e-liquids, potentially as a marketing tool ${ }^{6}$. Other marketing methods have included signage, promotional discounts, and the use of social media to attract customers ${ }^{2}$. While many vape shop owners rely on word of mouth, they also have used loyalty programs and free samples to promote their products ${ }^{2}$. Moreover, recent studies have found associations between e-cigarette advertising exposure and subsequent e-cigarette use among adolescents ${ }^{11,12}$. With the rapid rise in e-cigarette use among youth and young adults, and the limited regulations put on e-cigarette advertisements in general, it is imperative that research be conducted that informs on policies aimed at regulating e-cigarette marketing, especially marketing that 
occurs at point-of-sale venues.

Past research on the marketing efforts of tobacco companies has shown significant differences between the types and content of marketing material and a community's racial/ ethnic profile ${ }^{13-16}$. For example, there is consistent evidence showing a higher prevalence of deals/coupon in certain ethnic communities ${ }^{16-20}$. Recently, Cheney et al. $^{2}$ found that vape shop owners, similar to tobacco companies, reported regular use of discounts to attract and retain customers. The current study attempted to determine if differences exist in vape shop marketing practices across racial/ethnic communities. The findings could aid the tailoring of health promotion and education efforts within these communities in the hope of countering marketing effects and to provide information for policies aimed at regulating e-cigarette marketing in the future.

\section{METHODS}

Data were collected in 2014 from vape shops in the Los Angeles area. Data collection methods included interviews with the vape shop employees and in-store observations. A Yelp search was conducted to identify vape shops and we excluded stores considered tobacco shops or other stores (i.e. convenience stores) that sold items unrelated to vaping ${ }^{9}$ (see Sussman et al. 2014 for more details). Among the 104 shops identified and approached to be part of the study, 17 were no longer in business, 4 declined to participate, 4 were tobacco shops, 1 was an e-cigarette distributor, and 1 was hookah/vape lounge, resulting in a total of 77 shops for the final analytical sample.

Vape shops were located in communities with high proportions of African Americans $(\mathrm{n}=20)$, Hispanics $(\mathrm{n}=17)$, Koreans $(\mathrm{n}=18)$, and non-Hispanic Whites $(\mathrm{n}=22)$, representing the diversity of the greater Los Angeles area. USA Census data were used to identify the neighborhoods that contained certain concentrations of the populations of interest. Thresholds were created for ethnicities to identify an ethnic community: $8-32 \%$ of the neighborhood was Korean, $14-38 \%$ of African-Americans, $63-93 \%$ of Hispanics, and $70-85 \%$ of non-Hispanic Whites. For example, if $8-32 \%$ of a neighborhood's population identified as Korean it was considered a Korean neighborhood. The Yelp search was conducted for the neighborhoods until a minimum of 20 shops per community were identified. Only shops with 5 to 20 Yelp reviews were included ${ }^{9}$.

\section{Data Collection}

The study methods were deemed to be exempt for review by the University of Southern California Institutional Review Board (IRB \#HS-14-00217). Two data collectors visited each of the 77 vape shops. During their visit, they completed an in-store observation and conducted interviews with the store employees. Data collectors interviewed the shop owners, managers, or clerks based on who was available. All data collection was conducted in English. A \$50 gift card was given to each participant for the interview and for allowing in-store observation data collection. During data collection, one data collector would conduct the employee interview while the other conducted the in-store observation.

\section{Measures}

Employee Interview. Employees were asked about their age, gender, ethnicity, spoken languages, shop position, and length of employment. Employees were asked also about which products they sold at their shops and if they allowed free samples. If free samples were allowed, employees were asked about how their customers were notified of this service. Employees were asked about how they were informed of new products and how they decided on which products to keep in the shop.

Shop Observation Form. During the in-store observation, data collectors noted the presence of marketing material on display. These promotional displays included interior/ exterior signage (i.e. posters, flyers, brochures, chalkboards), coupons or other promotional discounts, advertisements for e-cigarettes, promotional material at the point of sale, and whether free samples containing nicotine were provided and/ or promoted. Data collectors also documented whether any of these promotional displays addressed the safety of e-cigarettes, smoking cessation, and whether they contained ethnic specific messages or images. Data collectors also recorded any deals or coupons available in the shop, and the types of products that were clearly visible.

\section{Analysis}

Univariate analysis was conducted to assess the demographic information and other vape shop characteristics. Means were reported for continuous variables and frequencies for categorical variables. Chi-square analysis was conducted to determine if vape shop marketing practices/characteristics differed across ethnic communities. Fisher's exact test was used in cases where the cell total was less than five. STATA 14.1 was used to conduct statistical analysis. Results were considered significant when $\mathrm{p}<.05$.

\section{RESULTS}

Out of the 77 shops in the sample, 1 shop also sold cigars and 2 shops sold pipe tobacco/pipes. None of the shops sold hookah 
or cigarettes, and $43 \%$ of them carried "No Smoking" signs. Most vape shop employees were male (86\%) with mean age of $28(\mathrm{SD}=8)$ years ranging from 18 to 59 years (Table 1$)$. About $26 \%$ of employees reported "Other" for ethnicity. The different job positions were represented in our sample, with owners

\section{Table 1. Demographic Information of the VapeShopOwners Employeesin 2014*}

\begin{tabular}{|c|c|c|}
\hline Total N 77 & $\mathbf{N}$ & $\%$ \\
\hline \multicolumn{3}{|l|}{ Community } \\
\hline African-American & 20 & 26 \\
\hline Hispanic & 17 & 22 \\
\hline Korean & 18 & 23 \\
\hline White & 22 & 29 \\
\hline \multicolumn{3}{|c|}{ Owner/Employee Demographics } \\
\hline & Mean & SD \\
\hline \multirow[t]{2}{*}{ Age } & 28 & 8 \\
\hline & $\mathrm{N}$ & $\%$ \\
\hline \multicolumn{3}{|l|}{ Gender } \\
\hline Male & 66 & 86 \\
\hline Female & 11 & 14 \\
\hline \multicolumn{3}{|l|}{ Ethnicity } \\
\hline $\begin{array}{l}\text { Korean (or other Asian } \\
\text { backgrounds) }\end{array}$ & 23 & 30 \\
\hline White & 21 & 27 \\
\hline Hispanic & 7 & 9 \\
\hline Other & 26 & 34 \\
\hline \multicolumn{3}{|l|}{ Job at the Store } \\
\hline Owner & 17 & 22 \\
\hline Owner/Manager & 2 & 3 \\
\hline Manager & 30 & 39 \\
\hline Clerk & 24 & 31 \\
\hline Clerk/Other & 1 & 1 \\
\hline Other & 3 & 4 \\
\hline
\end{tabular}

* Interviews were conducted with vape shop owners/employees in the greater Los Angeles region in 2014 representing $22 \%$, owner/manager $3 \%$, managers $39 \%$, clerks $31 \%$, clerk/other $1 \%$ and others $4 \%$ of the participants.

Based on the employee interviews, all of the shops allowed free trial puffs on e-cigarettes in the store and $58 \%$ of them used displays informing customers about this service. About half $(51 \%)$ of the shops permitted customers to have free samples that contained nicotine.

Table 2 displays data collected from the in-store observations. We found that $61 \%$ of vape shops had advertisements for e-cigarettes, while $84 \%$ of the shops used print information to communicate deals/coupons for e-cigarettes. Shops in Hispanic (94\%) communities had the highest prevalence of deals/ coupons offered followed by shops in African-American (90\%), non-Hispanic White (82\%), and Korean (72\%) communities. One shop in the African-American community also promoted a $10 \%$ discount for healthcare workers. About $18 \%$ of the shops displayed information regarding the safety of e-cigarettes, $13 \%$ had point-of-sales displays and about $10 \%$ had ethnicspecific signage. Vape shops in Hispanic communities (29\%) were more likely to have ethnic-specific signs (e.g. messages in another language) than other communities (Fisher's exact $=0.002$ ). Signage in Hispanic community stores included a sign portraying e-cigarettes as a healthier alternative written in Spanish on a store window and business cards with information in Spanish. There was no ethnic-specific signage in non-Hispanic White and African-American shops. East Asian language and symbols were displayed on store windows and inside Korean community stores.

About $83 \%$ of all shops had clearly visible self-service stations where customers could access free samples with differences observed across communities (Fisher's exact $=0.013$ ). All Korean stores and $91 \%$ of non-Hispanic White stores had visible self-service stations where customers could access free samples compared to $76 \%$ of stores in Hispanic communities and $65 \%$ of stores in African American communities.

Table 2. Measures of Marketing Promotion by Community Type in 2014

\begin{tabular}{|c|c|c|c|c|c|}
\hline & $\begin{array}{l}\text { African-American } \\
(n-20)\end{array}$ & Hispanic(n-17) & Korean (n-18) & $\begin{array}{c}\text { Non Ilispanic White } \\
(n-22)\end{array}$ & Total $(n-77)$ \\
\hline Point-of-sales displays & $2(10)$ & $0(0)$ & $4(22)$ & $4(18)$ & $10(13)$ \\
\hline Safety of e-cigarettes & $1(5)$ & $5(29)$ & $5(28)$ & $3(17)$ & $14(18)$ \\
\hline $\begin{array}{l}\text { Quit smoking } \\
\text { information or products } \\
\text { (e.g. Niko Stop) }\end{array}$ & $7(35)$ & $4(24)$ & $1(6)$ & $4(18)$ & $16(21)$ \\
\hline $\begin{array}{l}\text { Deals/Coupons for } \\
\text { e-cigarettes }\end{array}$ & $18(90)$ & $16(94)$ & $13(72)$ & $18(82)$ & $65(84)$ \\
\hline $\begin{array}{l}\text { Advertisements for } \\
\text { e-cigarettes }\end{array}$ & $12(60)$ & $10(59)$ & $12(67)$ & $13(59)$ & $47(61)$ \\
\hline Ethnic specific signage & $0(0)$ & $5(29)$ & $3(17)$ & $0(0)$ & $8(10)$ \\
\hline Other: & $6(30)$ & $5(29)$ & $6(33)$ & $10(46)$ & $27(35)$ \\
\hline
\end{tabular}




\section{DISCUSSION}

The present study is the first to examine the marketing practices of vape shops across ethnic communities in the USA. The findings show that vape shops often provide free samples to their customers, with this practice most common in Korean and non-Hispanic White communities. Free samples have been shown to attract new and returning customers to vape shops ${ }^{2}$. In a previous study ${ }^{21}$, it was found that a large majority of vape shops (85\%) allowed their customers to have samples containing a moderate level, 6-10 mg/mL, of nicotine. It must be noted however, that the FDA's deeming rule on e-cigarettes and other emerging tobacco products made it illegal for retailers to provide free samples. It is unclear at this point how vape shops will react to this new regulation. Vape shops may continue this practice unless enforcement is strong and penalties are severe. Other shops may charge a nominal fee, like a nickel, to sample products. In comparison, the tobacco industry responded to rules, handed down in the Master Settlement Agreement that changed cigarette marketing, by increasing price promotions once billboard ads, cartoon characters, branded merchandise, and brand sponsorship were banned ${ }^{22-25}$. Future research should focus on how vape shops will change their marketing practices.

There will also be a need for effective media campaigns that will communicate the risks of using e-cigarettes. The FDA has prohibited the distribution of tobacco products with modified risk claims, and these rules now apply to e-cigarettes. There were shops in our study that displayed marketing material that promoted e-cigarettes as a healthier alternative. These marketing materials could disseminate misinformation regarding the health safety of these products $^{26}$. The use of e-cigarette marketing has shown to be effective with young adults and smokers reporting positive views of e-cigarettes after exposure to e-cigarette advertisements ${ }^{6,27-30}$. Furthermore, young adults and youth have regarded e-cigarettes as a healthier modern alternative to combustible cigarettes ${ }^{31-34}$. Misleading information on marketing material and marketing practices that are targeted towards vulnerable populations (like youth and ethnic minorities) should be documented and regulated ${ }^{35}$. With regulations being put in place for the vape shop and e-cigarette industries, together with the current findings of the present study on the marketing activities taking place, it will be important for public health professionals to continue and expand research in this area.

Both national and local public health professionals should consider collaborating with community organizations when developing educational campaigns. This will help to ensure that the messaging on marketing material is appropriate for different ethnic communities.

\section{Limitations}

Data were cross-sectional and longitudinal studies are needed to observe how vape shop marketing practices respond to different pressures (i.e. regulatory, consumer, industry) and evolving customer demands. Understanding these responses will help in assessing the effect of regulatory actions on the promotion of e-cigarettes. Another limitation is the lack of an inter-rater reliability assessment for the in-store observations. One data collector conducted all the interviews; therefore, an inter-rater reliability assessment was not conducted. Results described herein may not represent the vape shop marketing practices in other areas of the USA. There is a need to compare the marketing practices of vape shops across the country to understand how marketing practices can differ, based on regulatory environment and the racial/ethnic profile of the region. A paper by Barker et al. in this special issue begins to contribute to this discussion by describing marketing practices in nine cities across the USA and more research should follow.

\section{CONCLUSIONS}

Research on the promotion of e-cigarettes in vape shops is beginning to expand ${ }^{2,6}$. The present study contributes to the associated literature by describing how marketing practices differ according to the community racial/ethnic profile. Further research and action in this area is needed in order to prevent the exacerbation of the burden of nicotine addiction in vulnerable populations. Many lessons can be learned from public health counter marketing campaigns that took place to combat tobacco marketing segmentation. Traditional tobacco companies have historically targeted ethnic minorities ${ }^{20}$ and the vaping industry could follow suit. Regulation in this area is difficult to accomplish so it will be the challenge of public health professionals to mitigate the resulting disparities.

\section{REFERENCES}

1 Lee YO, Kim AE. "Vape shops" and "E-Cigarette lounges" open across the USA to promote ENDS. Tob Control. 2015;24(4):410-412. doi:10.1136/tobaccocontrol-2013-051437

2. Cheney M, Gowin M, Wann TF. Marketing Practices of Vapor Store Owners. Am J Public Health. April 2015:e1-e6. doi:10.2105/AJPH.2015.302610

3. Cheney MK, Gowin M, Wann TF. Vapor Store Owner Beliefs about Electronic Cigarette Regulation. Tob Regul Sci. 2015;1(3):227-235. doi:10.18001/TRS.1.3.4

4. Carr ER. E-Cigarettes: Facts, Perceptions, and Marketing Messages 
- ProQuest. Clin J Oncol Nurs. 2014;18(1):112-116. Available at: http://search.proquest.com/openview/a7829ed88926a7f395fd0887 25def5f3/1?pq-origsite=gscholar. (Accessed July 2, 2015).

5. Wagoner KG, Song EY, Egan KL, et al. E-cigarette availability and promotion among retail outlets near college campuses in two southeastern states. Nicotine Tob Res. 2014;16(8):1150-1155. doi:10.1093/ntr/ntu081

6. Cheney MK, Gowin M, Wann TF. Vapor Store Owner Beliefs and Messages to Customers. Nicotine Tob Res. June 2015:ntv129-. doi:10.1093/ntr/ntv129

7. KimAE,Arnold KY,Makarenko O.E-cigarette advertising expenditures in the U.S., 2011-2012. Am J Prev Med. 2014;46(4):409-412. doi:10.1016/j.amepre.2013.11.003

8. Huang J, Kornfield R, Szczypka G, Emery SL. A cross-sectional examination of marketing of electronic cigarettes on Twitter. Tob Control. 2014;23(Supplement 3):iii26-iii30. doi:10.1136/tobaccocontrol-2014-051551

9. Sussman S, Garcia R, Cruz TB, Baezconde-garbanati L, Pentz MA, Unger JB. Consumers' perceptions of vape shops in Southern California: an analysis of online Yelp reviews. Tobacco Induced Diseases. Available at: http://www.biomedcentral.com/content/pdf/ s12971-014-0022-7.pdf. Published 2014. (Accessed April 23, 2015).

10. Allem J-P, Unger JB, Garcia R, Baezconde-Garbanati L, Sussman S. Tobacco Attitudes and Behaviors of Vape Shop Retailers in Los Angeles. Am J Health Behav. 2015;39(6):794-798. doi:10.5993/AJHB.39.6.7

11. Mantey DS, Cooper MR, Clendennen SL, Pasch KE, Perry CL. E-Cigarette Marketing Exposure Is Associated With E-Cigarette Use Among US Youth. J Adolesc Heal. 2016;58(6):686-690. doi:10.1016/j.jadohealth.2016.03.003

12. Villanti AC, Rath JM, Williams VF, et al. Impact of Exposure to Electronic Cigarette Advertising on Susceptibility and Trial of Electronic Cigarettes and Cigarettes in US Young Adults: A Randomized Controlled Trial. Nicotine Tob Res. 2016;18(5):13311339. doi:10.1093/ntr/ntv235

13. Cantrell J, Kreslake JM, Ganz O, et al. Marketing little cigars and cigarillos: advertising, price, and associations with neighborhood demographics. Am J Public Health. 2013;103(10):1902-1909. doi:10.2105/AJPH.2013.301362

14. Widome R, Brock B, Noble P, Forster JL. The relationship of neighborhood demographic characteristics to point-of-sale tobacco advertising and marketing. Ethn Health. 2013;18(2):136-151. doi:10.1080/13557858.2012.701273

15. Feighery EC, Schleicher NC, Boley Cruz T, Unger JB. An examination of trends in amount and type of cigarette advertising and sales promotions in California stores, 2002-2005. Tob Control. 2008;17(2):93-98. doi:10.1136/tc.2007.022046

16. Lee JGL, Henriksen L, Rose SW, Moreland-Russell S, Ribisl KM. A Systematic Review of Neighborhood Disparities in Point of Sale Tobacco Marketing. Am J Public Health. 2015;105(9):e8-e18. doi:10.2105/AJPH.2015.302777

17. Henriksen L, Schleicher NC, Dauphinee AL, Fortmann SP. Targeted advertising, promotion, and price for menthol cigarettes in California high school neighborhoods. Nicotine Tob Res. 2012;14(1):116-121. doi:10.1093/ntr/ntr122

18. Henriksen L, Feighery EC, Schleicher NC, Haladjian HH, Fortmann SP. Reaching youth at the point of sale: cigarette marketing is more prevalent in stores where adolescents shop frequently. Tob Control. 2004;13(3):315-318.

doi:10.1136/tc.2003.006577

19. Siahpush M, Jones PR, Singh GK, Timsina LR, Martin J. The association of tobacco marketing with median income and racial/ ethnic characteristics of neighbourhoods in Omaha, Nebraska. Tob Control. 2010;19(3):256-258.

doi:10.1136/tc.2009.032185

20. Yerger VB, Przewoznik J, Malone RE. Racialized geography, corporate activity, and health disparities: tobacco industry targeting of inner cities. J Health Care Poor Underserved. 2007;18(4 Suppl):10-38. doi:10.1353/hpu.2007.0120

21. Garcia R, Allem J, Baezconde-Garbanati L, Unger J, Sussman S. Employee and customer handling of nicotine-containing e-liquids in vape shops. Tob Prev Cessat. 2017;2(Supplement). doi:10.18332/tpc/67295

22. Wakefield MA, Terry-McElrath YM, Chaloupka FJ, et al. Tobacco Industry Marketing at Point of Purchase After the 1998 MSA Billboard Advertising Ban. Am J Public Health. 2002;92(6):937-940. doi:10.2105/AJPH.92.6.937

23. Celebucki CC, Diskin K. A longitudinal study of externally visible cigarette advertising on retail storefronts in Massachusetts before and after the Master Settlement Agreement. Tob Control. 2002;11:47-53. http://tobaccocontrol.bmj.com/content/tobaccocontrol/11/suppl_2/ ii47.full.pdf. (accessed June 5, 2017).

24. Chung PJ, Garfield CF, Rathouz PJ, Lauderdale DS, Best D, Lantos J. Youth targeting by tobacco manufacturers since the Master Settlement Agreement. Health Aff (Millwood). 2002;21(2):254-263. doi:10.1377/HLTHAFF.21.2.254

25. Loomis BR, Farrelly MC, Nonnemaker JM, Mann NH. Point of purchase cigarette promotions before and after the Master Settlement Agreement: exploring retail scanner data. Tob Control. 2006;15:140142 .

doi:10.1136/tc.2005.011262

26. Tan ASL, Bigman CA. E-cigarette awareness and perceived harmfulness: prevalence and associations with smoking-cessation outcomes. Am J Prev Med. 2014;47(2):141-149. doi:10.1016/j. amepre.2014.02.011

27. Pokhrel P, Fagan P, Kehl L, Herzog TA. Receptivity to e-cigarette marketing, harm perceptions, and e-cigarette use. Am J Health Behav. 2015;39(1):121-131. doi:10.5993/АJHB.39.1.13

28. Pepper JK, Emery SL, Ribisl KM, Brewer NT. How U.S. adults find out about electronic cigarettes: implications for public health messages. Nicotine Tob Res. 2014;16(8):1140-1144. doi:10.1093/ntr/ntu060

29. King BA, Alam S, Promoff G, Arrazola R, Dube SR. Awareness and ever-use of electronic cigarettes among U.S. adults, 2010-2011. Nicotine Tob Res. 2013;15(9):1623-1627. doi:10.1093/ntr/ntt013

30. Richardson A, Pearson J, Xiao H, Stalgaitis C, Vallone D. Prevalence, Harm Perceptions, and Reasons for Using Noncombustible Tobacco Products Among Current and Former Smokers. July 2014. Available at: http://ajph.aphapublications.org/doi/abs/10.2105/ AJPH.2013.301804. (Accessed March 14, 2016).

31. Choi K, Fabian L, Mottey N, Corbett A, Forster J. Young adults' favorable perceptions of snus, dissolvable tobacco products, and electronic cigarettes: findings from a focus group study. Am J Public Health. 2012;102(11):2088-2093. 


\section{Research paper}

doi:10.2105/AJPH.2011.300525

32. Choi K, Forster J. Characteristics Associated With Awareness, Perceptions, and Use of Electronic Nicotine Delivery Systems Among Young US Midwestern Adults. February 2013. Available at: http:// ajph.aphapublications.org/doi/abs/10.2105/AJPH.2012.300947. (accessed March 14, 2016).

33. Ambrose BK, Rostron BL, Johnson SE, et al. Perceptions of the relative harm of cigarettes and e-cigarettes among U.S. youth. Am J Prev Med. 2014;47(2 Suppl 1):S53-60. doi:10.1016/j.amepre.2014.04.016

34. Sutfin EL, McCoy TP, Morrell HER, Hoeppner BB, Wolfson M. Electronic cigarette use by college students. Drug Alcohol Depend. 2013;131(3):214-221. doi:10.1016/j.drugalcdep.2013.05.001

35. Grier SA, Kumanyika S. Targeted Marketing and Public Health. Annu Rev Public Health. 2010;31(1):349-369.

doi:10.1146/annurev.publhealth.012809.103607

CONFLICT OF INTERESTS The authors have completed and submitted the ICMJE Form for Disclosure of Potential Conflicts of Interest and none was reported.

\section{FUNDING}

This work was supported in part, by grant number P50CA180905 from the National Cancer Institute $(\mathrm{NCl})$ and Food and Drug Administration (FDA) Center for Tobacco Products (CTP), and from discretionary account funding. The $\mathrm{NCl} / F D A$ funding covered only aspects of the project that were under FDA regulatory authority at the time of data collection. The content is solely the responsibility of the authors and does not necessarily represent the official views of $\mathrm{NCl}, \mathrm{NIH}$ or the FDA.

PROVENANCE AND PEER REVIEW

Commissioned:

externally peer reviewed 